\title{
Wrapping colonic anastomoses: Omentoplasty versus a carrier- bound fibrin sealant
}

\author{
Ayman A Albatanony ${ }^{a, b}$, MD; Tarek M Rageh ${ }^{a, c}, M D ;$ \\ Mohamad A Radwand,e, MD
}

\author{
a) Menoufiya Faculty of Medicine, Egypt. \\ b) Qassim College of Medicine, KSA. \\ c) Al-Hayat private hospital, Jeddah, KSA. \\ d) Ain Shams Faculty of Medicine, Cairo, Egypt. \\ e) King Saud hospital, Unayzah, Qassim, KSA.
}

Introduction: A leak from an intestinal anastomosis is the complication most feared by the colorectal surgeon. The role of omentoplasty in securing colorectal anastomoses shows some controversy: being recommended by some authors, being of equivocal value to others and to be recommend against by a third group of authors. Collagen-bound fibrin sealant sheets have recently been used in many aspects of surgery; for example: Hernia, GI, ophthalmic, gynecologic \& obstetric, renal, vascular and cardiac surgeries; and many experimental animal studies proved its efficacy in securing GI anastomoses. The safety and feasibility of using collagen-bound fibrin sealant has been proven. Its application for sealing colonic anastomosis is a new field of its application and needs to be evaluated.

Aim: To evaluate and compare the efficacy of both omentoplasty and a newly introduced fibrin sealant; TachoSil ${ }^{\circledR}$; in decreasing the rate of anastomotic leakage in colorectal anastomoses.

Results: 97 patients were included; 48 in omentoplasty group and 49 in TachoSil ${ }^{\circledR}$ group. The rate of clinical leakage in omentoplasty group was $8.3 \%$ and in TachoSil ${ }^{\circledR}$ group was $2 \%$. Three out of four leakages in the omentoplasty group were sever (>500 cc/day) and the only case in TachoSil ${ }^{\circledR}$ group was less sever $(<500 \mathrm{cc} /$ day). The average hospital stay in omentoplasty group was 9.3 days and in TachoSil ${ }^{\circledR}$ group was 7.2 days $(P<0.05)$.

Conclusion: Omentoplasty proved no beneficial effect in sealing colonic anastomoses. There is a trend proving that TachoSil ${ }^{\circledR}$ is more effective than omentoplasty in preventing anastomotic leakage. The use of the collagen-bound fibrin sealant TachoSil ${ }^{\circledR}$ appears to be beneficial, being better than omentoplasty regarding the length of hospital stay and the severity of leakage, if leakage is inevitable.

\section{Introduction:}

A leak from an intestinal anastomosis is the complication most feared by the colorectal surgeon. Reported colonic anastomosis leak rates range from $1.5 \%$ up to $16 \%$ with mortality rates typically quoted between $10 \%$ and $20 \% .^{1}$.

Many factors were proven to affect the rate of anastomosis leakage; preoperative, intra-operative and postoperative. For example: age, sex, general fitness of the patient, anastomotic tension, resection in an emergency setting, tumour stage, distal site, the need for postoperative blood transfusion, fecal contamination, increased blood loss during surgery, low preoperative serum albumin level, steroid use and increased duration of surgery. ${ }^{2-6}$

In order to decrease the rate and the severity of anastomotic leakage and infective complications, several methods have been proposed such as antibiotic prophylaxis, 
colonic preparation with antiseptic enemas, fecal diversion for protecting high-risk anastomoses, biofragmentable anastomosis ring and pelvic irrigation. ${ }^{7}$ External coating of anastomoses with various materials has been proposed as a means to reduce the leakage rate. ${ }^{8}$

The omentum has long been used in gastrointestinal, cardiothoracic, neurological, gynaecological, orthopaedic, vascular, urological, plastic and reconstructive surgeries. ${ }^{9}$

The role of omentoplasty in securing anastomoses after oesophageal resections is well-established. ${ }^{10}$ Its role in securing colorectal anastomoses shows some controversy: being recommended by some authors, ${ }^{11-13}$ to be of equivocal value to others ${ }^{7}$ and to recommend against by a third group of authors. ${ }^{14}$

Performing an omentoplasty is not without risks. Although uncommon, complications such as haemorrhage, necrosis of omentum and attribution to an internal herniation have been described. ${ }^{14}$

Even though technical modifications have decreased the rate of leakage in colonic anastomosis, the high mortality and severe morbidity in patients suffering from anastomotic leakage justify the necessity for evaluation of additional methods for decreasing the rate of anastomotic failure in these operations. ${ }^{15}$

Collagen-bound fibrin sealant sheets have recently been used in many aspects of surgery; for example: Hernia, ${ }^{16}$ Gastro-intestinal, ${ }^{17,18}$ ophthalmic, ${ }^{19}$ gynecologic \& obstetric, ${ }^{20}$ renal, ${ }^{21}$ vascular $^{22}$ and cardiac $^{23,24}$ surgeries; and many experimental animal studies proved its efficacy in securing GI anastomoses. ${ }^{25-27}$

In 2010, Huh et al. performed a prospective study involving 223 patients with rectal cancer who underwent laparoscopic resection. One group underwent surgery followed by application of fibrin sealant over the stapled anastomosis, while the other group underwent surgery alone. The clinical leakage rate was $5.8 \%$ for the fibrin group and $10.9 \%$ for the other group. ${ }^{28}$

De Stefano et al in 2011 conducted a study on 63 open resective colorectal surgeries and concluded: "Our initial experience with TachoSil ${ }^{\circledR}$ has confirmed the safety of this patch and we can therefore suggest a possible positive effect on anastomotic healing". ${ }^{29}$

In 2012, Parker et $\mathrm{al}^{17}$ concluded that the application of $\mathrm{TachoSil}^{\circledR}$ to reinforce the anastomotic line in colorectal resections appears to be feasible and well tolerated in most circumstances.

Aim of the work: In this study we are evaluating and comparing the efficacy of both omentoplasty and a newly introduced fibrin sealant; TachoSil ${ }^{\circledR}$; in decreasing the rate of anastomotic leakage in colorectal anastomoses.

\section{Patients and methods:}

The study is carried out between May 2010 and April 2013 in 3 hospitals; namely: Menoufiya University hospital, Shibin Alkom, Egypt, King Saud hospital, Unayzah, KSA and Al-Hayat Private hospital, Jeddah, KSA. The study is prospective and patients' choice will be on consecutive basis; being alternating between both using omentoplasty and $\mathrm{TachoSil}^{\circledR}$ patch to externally wrap the completed anastomosis. The study is approved by the appropriate authority in each hospital. The colon will be chemically and mechanically prepared, thus patients undergoing emergency surgery will not be included. Patients with known allergy to any of the components of collagen-bound fibrin sealants will be excluded from the study.

Surgical technique: The surgical technique for resection anastomosis will be standardized according to the ASCRS Manual of Colon and Rectal Surgery. ${ }^{30}$ Drainage of the abdominal cavity will be left to the choice of each surgeon.

In this study we will include only the clinically evident anastomotic leakage, thus the investigation for leakage will start on clinical basis i.e. if the patient is suffering abdominal pain, tenderness, fever, and/or leucocytosis. The occurrence of anastomotic leakage will be evidenced by the presence of fecal discharge through the pelvic drain left intra-operatively or inserted after radiological 
evidences of leakage. Gastrograffin enema for detection of preclinical leakage will not be performed on routine basis.

All operations will be carried out by 3 surgeons using either hand sewn or a stapled technique without a protective stoma. After completing the anastomosis, and testing for air tightness, ${ }^{31}$ the patient will be assigned to either covering the anastomosis with an omentoplasty or with a TachoSil ${ }^{\circledR}$ patch.

Omentoplasty is defined as "A surgical procedure in which a portion of the greater omentum is used to cover or fill a defect, augment arterial or portal venous circulation, absorb effusions, or increase lymphatic drainage". 32

We will follow the standard surgical techniques while performing omentoplasty, making sure that the vascular pedicle is intact, taking in consideration the valuable notes by Topor et al. ${ }^{12}$

TachoSil $^{\circledR}$ is a registered trademark of Nycomed Pharma AS. It is a sterile, ready touse, absorbable surgical patch consisting of an equine collagen sponge coated with human fibrinogen and human thrombin measuring $9.5 \times 4.8 \times 0.5 \mathrm{~cm}$. This new carrier bound fibrin sealant was approved by the FDA, 33 the Scottish Medicines Consortium, ${ }^{34}$ and the European Medicines Agency - Committee for Medicinal Products for Human Use. 35

While using TachoSil ${ }^{\circledR}$ patch, it will be pressed gently over the anastomotic line for 1-3 minutes, making sure that the sheet covered and adhered to at least one $\mathrm{cm}$ on each side of the anastomosis.

In each patient, we will record the following data (among others) ${ }^{36}$ : Age, gender, American society of anesthesiologists score (ASA) score, body mass index (BMI), smoking, alcoholism, steroids, neo-adjuvant therapy, site of anastomosis, intra-operative blood loss, post-operative blood transfusion, duration of surgery, use of drain, clinical leakage, severity of leakage, hospital stay, postoperative complication, postoperative mortality, anastomosis done manual or mechanical and time of evidence of GIT movement.

Each of these factors will be compared between both groups with two intents: testing for homogenousity of the demographic data between the two groups, as well as comparing the outcomes. Patients will be followed up for 45 days postoperatively for evidences of leakage and other surgery-related complications. The average cost of TachoSil ${ }^{\circledR}$ patch per patient will be calculated.

Statistical analysis: The data collected were tabulated and analyzed using SPSS statistical package version 12 on IBM compatible computer. Groups were compared using the Chi square test for categorical variables and Student's t-test for continuous variables. Qualitative data were expressed as number and percentage (No and \%) and analyzed by applying Chi-square test (X2 test). All these tests were used as tests of significance at $\mathrm{P}<0.05$.

\section{Results:}

97 patients were included in this study, with an average of 11 patients per year for each hospital during the study period (3 years). We excluded one patient from the study who was found to have an atrophied omentum. We encountered no patients with allergy to any of the components of the collagen-bound fibrin sealant used in this study.

When the omentum was mobilized, it was most often based on the left gastroepiploic artery and it was wrapped loosely around the suture line, and fixed to the colonic segments proximally and distally by separate sutures. The average cost of TachoSil ${ }^{\circledR}$ patches per patient was 210 US Dollars. The mean postoperative stay in TachoSil ${ }^{\circledR}$ group was 7.2 days, and in omentoplasty group was 9.3 days $(\mathrm{P}<0.05)$.

Table (1) represents the results of the study. A comparison between the two groups was done, taking the significance level to be at or less than $0.05 \%$.

\section{Discussion:}

The uncomplicated healing of an intestinal anastomosis even after attentive technical performance from an experienced surgeon is still a challenge because the healing process is dependent on multiple physiological, 
Table 1: the results of the study and a comparison between the two groups.

\begin{tabular}{|c|c|c|c|c|}
\hline \multicolumn{2}{|c|}{ Item } & $\begin{array}{l}\text { Omentoplasty } \\
\mathrm{N}=48 \text { patients }\end{array}$ & $\begin{array}{c}\text { TachoSil }{ }^{\circledR} \\
\mathrm{N}=49 \text { patients }\end{array}$ & $P$ value \\
\hline \multicolumn{2}{|l|}{ Age (years) } & $48.87 \pm 6.43$ & $51.51 \pm 9.68$ & 0.11 \\
\hline \multirow[t]{2}{*}{ Gender } & Male & $30 / 48$ & $27 / 49$ & \multirow[t]{2}{*}{0.45} \\
\hline & Female & $18 / 48$ & $22 / 49$ & \\
\hline \multirow[t]{4}{*}{ ASA Score } & I & $5 / 48$ & $6 / 49$ & \multirow[t]{4}{*}{0.74} \\
\hline & II & $20 / 48$ & $25 / 49$ & \\
\hline & III & $18 / 48$ & $14 / 49$ & \\
\hline & IV & $5 / 48$ & $4 / 49$ & \\
\hline \multirow[t]{2}{*}{ BMI } & 30 and above & $3 / 48$ & $4 / 49$ & 0.71 \\
\hline & $\begin{array}{l}\text { Loss of }>5 \mathrm{~kg} \text { in } \\
6 \text { months }\end{array}$ & $11 / 48$ & $14 / 49$ & 0.52 \\
\hline \multirow[t]{2}{*}{ Smoking } & yes & $22 / 48$ & $17 / 49$ & \multirow[t]{2}{*}{0.26} \\
\hline & No & $26 / 48$ & $32 / 49$ & \\
\hline \multirow[t]{2}{*}{ Alcoholism } & yes & $3 / 48$ & $2 / 49$ & \multirow[t]{2}{*}{0.62} \\
\hline & no & $45 / 48$ & $47 / 49$ & \\
\hline \multirow[t]{2}{*}{ Steroids } & yes & $1 / 48$ & $1 / 49$ & \multirow[t]{2}{*}{0.98} \\
\hline & no & $47 / 48$ & $48 / 49$ & \\
\hline \multirow{3}{*}{$\begin{array}{l}\text { Neo-adjuvant } \\
\text { Therapy }\end{array}$} & Radiotherapy & $1 / 48$ & $0 / 49$ & \multirow[t]{3}{*}{0.29} \\
\hline & Chemo-radiation & $10 / 48$ & $6 / 49$ & \\
\hline & No & $37 / 48$ & $43 / 49$ & \\
\hline \multirow{3}{*}{$\begin{array}{l}\text { Site of } \\
\text { anastomosis }\end{array}$} & Right colon & $9 / 48$ & $9 / 49$ & \multirow[t]{3}{*}{0.84} \\
\hline & Left colon & $11 / 48$ & $9 / 49$ & \\
\hline & rectum & $28 / 48$ & $31 / 49$ & \\
\hline \multirow{3}{*}{$\begin{array}{l}\text { Intra-operative } \\
\text { blood loss }\end{array}$} & Less than 500 & $8 / 48$ & $5 / 49$ & \multirow[t]{3}{*}{0.46} \\
\hline & $500-1000$ & $22 / 48$ & $28 / 49$ & \\
\hline & More than 1000 & $18 / 48$ & $16 / 49$ & \\
\hline \multirow{2}{*}{$\begin{array}{l}\text { Post-operative } \\
\text { blood transfusion }\end{array}$} & yes & $11 / 48$ & $6 / 49$ & \multirow[t]{2}{*}{0.16} \\
\hline & no & $37 / 48$ & $43 / 49$ & \\
\hline \multirow{3}{*}{$\begin{array}{l}\text { Duration of } \\
\text { surgery (minutes) }\end{array}$} & Less than $2 \mathrm{~h}$ & $9 / 48$ & $7 / 49$ & \multirow[t]{3}{*}{0.75} \\
\hline & 2-4 hours & $28 / 48$ & $32 / 49$ & \\
\hline & More than $4 \mathrm{~h}$ & $11 / 48$ & $10 / 49$ & \\
\hline \multirow[t]{2}{*}{ Use of drain } & yes & 22 & 17 & \multirow[t]{2}{*}{0.26} \\
\hline & No & 26 & 32 & \\
\hline \multirow[t]{2}{*}{ Clinical leakage } & yes & $4 / 48$ & $1 / 49$ & \multirow[t]{2}{*}{0.16} \\
\hline & No & $44 / 48$ & $48 / 49$ & \\
\hline \multirow{2}{*}{$\begin{array}{l}\text { Severity of } \\
\text { leakage }\end{array}$} & Less than 500 & $1 / 4$ & $1 / 1$ & 0.17 \\
\hline & More than 500 & $3 / 4$ & $0 / 4$ & \\
\hline Hospital stay (days & & $9.3 \pm 2.1$ & $7.2 \pm 1.9$ & $<0.05$ \\
\hline
\end{tabular}




\begin{tabular}{|l|l|l|l|l|}
\hline \multicolumn{2}{|c|}{ Item } & \multicolumn{1}{|c|}{$\begin{array}{c}\text { Omentoplasty } \\
\text { N=48 patients }\end{array}$} & $\begin{array}{c}\text { TachoSil }{ }^{\circledR} \\
\text { N=49 patients }\end{array}$ & P value \\
\hline $\begin{array}{l}\text { Post-operative } \\
\text { Complication }\end{array}$ & $\begin{array}{l}\text { Wound } \\
\text { complication }\end{array}$ & $6 / 48$ & $7 / 49$ & 0.79 \\
\cline { 2 - 5 } & $\begin{array}{l}\text { Chest \& UTI } \\
\text { infections }\end{array}$ & $13 / 48$ & $14 / 49$ & 0.87 \\
\cline { 2 - 5 } & DVT & $3 / 48$ & $7 / 49$ & 0.19 \\
\hline Postoperative mortality & $1 / 48$ & $0 / 49$ & 0.31 \\
\hline $\begin{array}{l}\text { Anastomosis } \\
\text { done... }\end{array}$ & Manual & $14 / 48$ & $20 / 49$ & 0.22 \\
\cline { 2 - 5 } & Mechanical & $34 / 48$ & $29 / 49$ & $<0.05$ \\
\hline \multicolumn{2}{|l|}{ Time of evidence of GIT movement } & $6.5 \pm 1.52$ days & $4.8 \pm 1.15$ days & $<$ \\
\hline
\end{tabular}

biochemical, and morphological factors. ${ }^{37}$

Anastomotic leaks are detected anywhere from 3 to 45 days postoperatively, and the diagnosis is mostly made between days 6 and 9. However, it stands to a reason that the processes which lead to the failure start much earlier, probably in the immediate postoperative period when the wound strength is believed to be low. ${ }^{27}$

In our study, omentoplasty proved to be simple to perform and not time consuming, as evidenced by comparing the operative time between the two groups, where no statistically proven difference was noticed between the two groups $(\mathrm{P}>0.05)$. No complication was noted due to the use of omentoplasty in our study during the follow up period. One limitation for the use of omentoplasty is atrophy of the omentum which may be congenital or acquired. ${ }^{38}$

Anastomotic leakage after colectomy is one of the most serious complications in colorectal surgery. Best defined as "leak of luminal contents from a surgical join between 2 hollow viscera," its incidence ranges from $2 \%$ to $4 \%$ with proximal anastomosis, to $6 \%$ to $12 \%$ with distal extraperitoneal anastomosis, and is associated with mortality rates of $10-30 \% .^{3}$

When comparing the two groups regarding the demographic data and other factors Table (1); there was no statistically significant difference between both groups ( $>00.05$ ), except in the length of hospital stay and the time of evidence of GIT movement (where $\mathrm{p}<0.05$ ).
The overall incidence of anastomotic leakage in this study is $5.15 \%(5 / 97)$, which is towards the lowest rate reported in other studies; ${ }^{1}$ this may be attributed to the patient selection, as we excluded from this study all emergency colectomies. Emergency colectomy is well-documented to be associated with higher incidence of anastomotic leakage. ${ }^{37}$

We excluded the emergency colectomies from this study due to a previous work by Chmelnik et al. ${ }^{39}$ Their experimental study in rats showed severe pre-anastomotic dilatation in additionally sealed small-diameter anastomoses when using a fibrin-coated collagen patch. They attributed this finding to increased inflammation as a result of bacterial contamination and a disproportion between bowel wall and patch thickness. They reported: "As a result of our findings, the application of $\mathrm{TachoSil}^{\circledR}$ in smalldiameter intestinal anastomoses cannot be recommended. Whether TachoSil ${ }^{\circledR}$ generally can be safely used in bacterially contaminated tissues needs to be investigated in future studies”. Thus, we excluded emergency colectomies to avoid applying TachoSil ${ }^{\circledR}$ in a heavily contaminated tissue.

Most of the recently published studies ${ }^{40,41}$ suggest that mechanical bowel preparation is of no value regarding the anastomotic integrity; a point that is in favour of omentoplasty and against $\mathrm{TachoSil}^{\circledR}$. As already mentioned, it is better to avoid using TachoSil ${ }^{\circledR}$ in the presence of heavy bacterial contamination, ${ }^{39}$ while such recommendation 
is not applicable with omentoplasty. Colon preparation with antibiotics has recently been proved beneficial. 42

The rate of leakage in the TachoSil ${ }^{\circledR}$ group was $2 \%(1 / 49)$; while in the omentoplasty group it was $8.3 \%$ (4/48), which implies no beneficial effect of omentoplasty in preventing anastomotic leakage. This is in accordance with the most recent publication in this field. 43

When comparing the 2 groups, we found no statistically significant difference between the incidences of leakage after omentoplasty compared to the application of collagen-bound fibrin sealant $(\mathrm{P}>0.05)$. However, the study showed that there is a trend of the collagenbound fibrin sealant to be more effective than omentoplasty, because the rate was 4 cases in the omentoplasty group and one case in the TachoSil ${ }^{\circledR}$ group. Failure to demonstrate a statistically significant difference may be due to the relatively small number of the cases included in this study.

Another finding in our study is that: if leakage is going to occur, it tends to be less severe in the TachoSil ${ }^{\circledR}$ group compared to the omentoplasty group. Three out of four leakages in the omentoplasty group were severe leakages (> $500 \mathrm{cc}$ per day), while the single case of leakage in TachoSil ${ }^{\circledR}$ group was less severe ( $<500$ cc day). This can be attributed to the difference in the mechanism of action between omentoplasty and TachoSil ${ }^{\circledR}$ in sealing the anastomosis.

Omentoplasty works to protect the anastomosis in many ways:

When placed in contact with an anastomotic gap, an entirely viable omentum forms an effective bridge over anastomotic defects and responds with an outgrowth of richly vascular tissue, which acts as the major vascular source to the wound. Omentoplasty provides an adherent sleeve that plugs or locally contains early anastomotic leakages during the dangerous period before revascularization occurs. The stimulated neo-angiogenesis and the richly vascularised tissue also could act as protective factors, lowering the incidence of anastomotic stricture. 13

The mechanism of action of TachoSil ${ }^{\circledR}$ follows the principles of physiological fibrin clot formation. Upon contact with a bleeding or leaking wound surface, or triggered by the presence of physiological saline, the coating of the collagen sponge dissolves and the subsequent thrombin-fibrinogen reaction initiates the last step of the coagulation cascade: Fibrinogen is converted by the action of thrombin into fibrin monomers which spontaneously polymerise to a fibrin clot. Thrombin can also activate endogenous factor XIII which covalently cross-links the fibrin to create a firm and stable fibrin network. ${ }^{35}$

This stable fibrin clot leads to sealing of the anastomosis in many ways: the physical barrier created by the fibrin clot, the facilitation of tissue approximation, the promotion of tissue healing by the components, and the creation of adhesion with surrounding tissues. ${ }^{28}$

These mechanisms of action of TachoSil ${ }^{\circledR}$ are reflected in our study: both the rate and the severity of leakage are lower in the TachoSil ${ }^{\circledR}$ group than the omentoplasty group.

In the postoperative period, the bowel anastomosis should be able to withstand forces in different directions. The bursting pressure, which reflects the capacity of the anastomosis to resist intra-luminal forces, is a good marker to test anastomotic strength. ${ }^{44}$ Many researchers examined the effect of fibrin sealant on the bursting pressure following anastomoses and proved a beneficial effect. ${ }^{45,46}$

It is known that colonic anastomoses are most fragile on days 3 and 4 because of low collagen content mediated by high activity of colonic collagenase induced by injury to the bowel wall during the healing phase of the anastomosis and on day 7 after anastomosis, collagenolytic activity reverts to normal values. ${ }^{15}$

We should stress that collagen-bound fibrin sealants are different from the earlier fibrin glues. Early studies on using fibrin glues to seal colon anastomoses were disappointing, with evidence that the glue inhibited wound healing and decreased anastomotic strength, burst strength, and collagen deposition at 
treated wound sites. Fibrin glues may also inhibit macrophage migration and neutrophil function. 25,27

In our study, when we compared both groups regarding the timing of regaining gastrointestinal movement, we found a statistically significant result proving that omentoplasty, in some way; delays the recovery of gastrointestinal movement. This result was reported in a previous study. ${ }^{14}$ In this aforementioned study, the authors explained that the mechanisms involved, are the presence of a pedicled omentum in the abdominalcavity causinga relativemechanical obstruction and the devascularization of the greater curvature of the stomach, thus delaying gastric functioning.

The safety of TachoSil ${ }^{\circledR}$ in sealing of gastrointestinal anastomoses with a collagen patch coated with fibrin components has been proven before in a study by Nordentoft et al. ${ }^{26}$ Their study revealed equal healing strength, and complication rate after sealing with a collagen patch coated with fibrin glue components compared with unsealed anastomoses. Furthermore, they found no difference in stenoses of the anastomoses. Another reported value of Fibrin sealants is decreasing intra-abdominal adhesions. ${ }^{47}$ Furthermore, one study proved TachoSil ${ }^{\circledR}$ has no negative physiological or histological side effects. ${ }^{26}$ Also, the feasibility of the application of TachoSil ${ }^{\circledR}$ for sealing colorectal anastomosis was proven. ${ }^{17}$

A shorter mean postoperative stay of 7.2 days was observed for patients where TachoSil ${ }^{\circledR}$ was applied compared to 9.3 days for patients of no- TachoSil ${ }^{\circledR}$. This difference was mainly related to anastomotic insufficiencies recorded in the no- TachoSil ${ }^{\circledR}$ group. This was in accordance with a recent study from Italy. ${ }^{29}$

Another point against TachoSil $^{\circledR}$ is the possibility of transmission of bloodborn diseases. There is a potential risk of transmission of micro-organisms from the blood samples that are used to produce $\mathrm{TachoSil}^{\circledR}$, even if, according to the manufacturer, blood comes only from selected donors and all the active measures against enveloped viruses are used. ${ }^{48}$

In a comprehensive review of External coating of colonic anastomoses, Pommergaard et $\mathrm{al}^{8}$ concluded that the only beneficial effect of all the fibrin sealants was that of using TachoSil ${ }^{\circledR}$.

In our study, the average coast per patient in the TachoSil ${ }^{\circledR}$ group was 210 USD, which could be an argument against its use. This extra-coast could be compensated for, at least in part, by the shorter hospital stay. In our study, the TachoSil ${ }^{\circledR}$ group patients stayed for a shorter time in hospital and the difference from the omentoplasty group is statistically significant $(\mathrm{P}<0.05)$. This finding was reported before. 49

One more argument against TachoSil ${ }^{\circledR}$ is its being a source of fibrin, thus it may lead to increase in the incidence of thrombotic complications postoperatively. In our study, there is a slight increase in the incidence of DVT in the TachoSil ${ }^{\circledR}$ group compared to the omentoplasty group, but it was not statistically significant $(\mathrm{P}<0.05)$. The main effect of TachoSil ${ }^{\circledR}$ is the local activation of the coagulation cascade leading to the local deposition of stable fibrin network. ${ }^{35}$ Whether or not this activation of the coagulation cascade can reach the systemic circulation needs further study.

\section{Conclusion :}

Within the limitation of the patient number included in this study, we conclude that omentoplasty proved no beneficial effect in sealing colonic anastomoses. There is a trend proving that $\mathrm{TachoSil}^{\circledR}$ is more effective than omentoplasty in preventing anastomotic leakage. The use of the collagen-bound fibrin sealant TachoSil ${ }^{\circledR}$ appears to be beneficial, being better than omentoplasty regarding the length of hospital stay, the timing of GIT movement and the severity of leakage, if leakage is inevitable. We agree with Konstantinos et $\mathrm{al}^{42}$ who reported: "the field of tissue adhesives is gaining ground in GI surgery. Despite years of research, the ideal tissue adhesive is yet to be found; however, the benefits of using adhesives are becoming more apparent”. 


\section{Conflict of interests:}

The authors declare that they have no conflict of interests.

\section{Reference:}

1- Thornton M, Joshi M, Vimalachandran C, Heath R, Carter P, Gur U, Rooney PP: Management and outcome of colorectal anastomotic leaks. Int J Colorectal Dis 2011; 26: 313-320.

2- Boccola MA, Buettner PG, Rozen WM, Siu SK, Stevenson AR, Stitz R, Ho YH: Risk factors and outcomes for anastomotic leakage in colorectal surgery: A single-institution analysis of 1576 patients. World J Surg 2011; 35: 186-195.

3- Leichtle SW, Mouawad NJ, Welch KB, Lampman RM, Cleary RK: Risk factors for anastomotic leakage after colectomy. Dis Colon Rectum 2012; 55: 569-575.

4- Suding P, Jensen E, Abramson MA, Itani K \& Wilson SE: Definitive risk factors for anastomotic leaks in elective open colorectal resection. Arch Surg 2008; 143(9): 907-912.

5- Telem DA, Chin EH, Nguyen SQ, Divino CM: Risk factors for anastomotic leak following colorectal surgery: A case-control study. Arch Surg 2010; 145(4): 371-376.

6- Hyman NH: Managing anastomotic leaks from intestinal anastomoses. Surgeon 2009; 7(1): 31-35.

7- Hao XY, Yang KH, Guo TK, Ma B, Tian $\mathrm{JH}, \mathrm{Li}$ HL: Omentoplasty in the prevention of anastomotic leakage after colorectal resection: A meta-analysis. Int $J$ Colorectal Dis 2008; 23: 1159-1165.

8- Pommergaard HS, Achiam MP, Rosenberg J: External coating of colonic anastomoses: A systematic review. Int J Colorectal Dis 2012; 27: 1247-1258.

9- Alagumuthu M, Das BB, Pattanayak SP, Rasananda M: The omentum: A unique organ of exceptional versatility. Indian J Surg 2006; 68(3): 136-141.

10- Dai JG, Zhang ZY, Min JX, Huang XH, Wang JS: Wrapping of the omental pedicle flap around esophago-gastric anastomosis after esophagectomy for esophageal cancer. Surgery 2011; 149 (3): 404-410.

11- Nilsson PJ: Omentoplasty in abdominoperineal resection: A review of the literature using a systematic approach. Dis Colon Rectum 2006; 49(9): 1354-1361.

12- Topor B, Acland RD, Kolodko V, Galandiuk S: Omental transposition for low pelvic anastomoses. Am J Surg 2001; 182: 460-464.

13- Tocchi A, Mazzoni G, Lepre L, Costa G, Liotta G, Agostini N, Miccini M: Prospective evaluation of omentoplasty in preventing leakage of colorectal anastomosis. Dis Colon Rectum 2000; 43(7): 951-955.

14- Klaver YL, Nienhuijs SW, Nieuwenhuijzen GA, Rutten HJ, de Hingh IH: Omentoplasty in rectal cancer surgery prolongs postoperative ileus. Int J Colorectal Dis 2008; 32: 165-169.

15- Hoeppner J, Wassmuth B, Marjanovic G, Timme S, Hopt UT, Keck T: Anastomotic sealing by extracellular matrices (ecm) improves healing of colonic anastomoses in the critical early phase. J Gastrointest Surg 2010; 14: 977-986.

16- Arslani N, Gajzer B, Papes D, Rajkovic Z, Altarac S, Zore Z, Filipovic-Zore I: A new approach for transversalis fascia reinforcement in Lichtenstein's inguinal hernia repair. Surg Today 2013; 43: 211-214.

17- Parker MC, Pohlen U, Borel Rinkes IHM, Delvin T: The application of TachoSil ${ }^{\circledR}$ for sealing colorectal anastomosis: A feasibility study. Colorectal Dis 2013; 15(2): 252-257.

18- Montorsi M, Zerbi A, Bassi C , Capussotti L, Coppola R, Sacchi M: Efficacy of an absorbable fibrin sealant patch $\left(\right.$ TachoSil ${ }^{\circledR}$ ) after distal pancreatectomy: A multicenter, randomized, controlled trial. Ann Surg 2012; 256(5): 853-860.

19- Grau, Arturo E \& Duran, Juan A: Treatment of a large corneal perforation with a multilayer of amniotic membrane and TachoSil ${ }^{\circledR}$. Cornea 2012; 31(1): 98-100.

20- Santulli P, Marcellin L, Touboul C, Ballester M, Darai E, Rouzier R: Experience with TachoSil ${ }^{\circledR}$ in obstetric and gynecologic surgery. Int J Gyn Obst 2011; 113(2): 112-115.

21- De Rosa P, Valeriani G, Barbato G, Cerbone V, Ciccone M, Russo E, Vicedomini D: Renal postexplant residual cavity hemostasis with a TachoSil ${ }^{\circledR}$ patch. Transplantation Proceedings 2011; 43(4): 1069-1071.

22- Dregelid E, Ramnefjell MP, Erichsen CC, Bjarn J, Rawal R: Effective hemostasis in severe mesenteric vein laceration with TachoSil ${ }^{\circledR}$, using a low- or non-thrombogenic patch to prevent $\mathrm{TachoSil}^{\circledR}$-induced thrombosis. Eur J Trauma Emerg Surg 2008; 34(2): 177-180.

23- Kuschel TA, Gruszka A, Hermanns-Sachweh B, Elyakoubib J, Sachweh JS, VazquezJimenez JF, Schnoering H: Prevention of 
postoperative pericardial adhesions with TachoSil $^{\circledR}$. Ann Thorac Surg 2013; 95(1): 183-188.

24- Pocar M, Passolunghi D, Bregasi A, Donatelli F: TachoSil ${ }^{\circledR}$ for postinfarction ventricular free wall rupture. Int CardioVasc Thorac Surg 2012; 14: 866-868.

25- Vuocolo T, Haddad R, Edwards GA, Lyons RE, Liyou NE, Werkmeister JA, Ramshaw JA, Elvin CM: A highly elastic and adhesive gelatin tissue sealant for gastrointestinal surgery and colon anastomosis. J Gastrointest Surg 2012; 16: 744-752.

26- Nordentoft T, Rømer J, Sørensen M: Sealing of gastrointestinal anastomoses with a fibrin glue-coated collagen patch: A safety study. $J$ Invest Surg 2007; 20: 363-369.

27- Der Vijver RJ, Laarhoven CJ, de Man BM, Lomme RM, Hendriks T: The effect of fibrin glue on the early healing phase of intestinal anastomoses in the rat. Int $J$ Colorectal Dis 2012; 27: 1101-1107.

28- Huh JW, Kim HR, Kim YJ: Anastomotic leakage after laparoscopic resection of rectal cancer: the impact of fibrin glue. Am J Surg 2010; 199(4): 435-441.

29- De Stefano A, Bettarini F, Di Mare G, Neri A: Enteric anastomosis and TachoSil ${ }^{\circledR}$. Minerva Chir 2011; 66(3): 183-188.

30- WexnerSD, Stamos MJ, Rombeau JL, Roberts PL, Beck DE: The ASCRS manual of colon and rectal surgery (different chapters) ISBN: 978-0-387-73438-5, DOI: 10.1007/978-0387-73440-8, Springer Science \& Business Media 2009, New York, USA.

31- Beard JD, Nicholson ML, Sayers RD, et al: Intraoperative air testing of colorectal anastomoses: A prospective randomized trial. Br J Surg 1990; 77: 1095-1097.

32- Omentoplasty: (n.d.): The American Heritage $^{\circledR}$ Stedman's Medical Dictionary. Retrieved March 25, 2013, from Dictionary. com: web: http://dictionary.reference.com/ browse/omentoplasty

33- Wamberg C: TachoSil ${ }^{\circledR}$. Vaccines, Blood \& Biologics. April 2, 2010 Approval Letter.

34- Scottish Medicines Consortium. TachoSil ${ }^{\circledR}$ medicated sponge. NHS Scotland 12 January 2007. http://www.scottishmedicines.org. uk.pdf

35- Scientific Discussion: This module reflects the initial scientific discussion for the approval of TachoSil ${ }^{\circledR}$. For information on changes after approval please refer to module 8. EMEA 2005.http://www.ema.europa.eu/ docs/en.pdf
36- Dekker JWT, Liefers GJ, Otterloo JCD, Putter H, Rob AEM. Tollenaar RAM: Predicting the risk of anastomotic leakage in left-sided colorectal surgery using a colon leakage score. J Surg Res 2011; 166: 27-34.

37- Trencheva K, Morrissey KP, Wells M, Mancuso CA, Lee SW, Sonoda T, Michelassi F, Charlson ME, Milsom JW: Identifying important predictors for anastomotic leak after colon and rectal resection: Prospective study on 616 patients. Ann Surg 2012; 257: 108-113.

38- Ali SD, Sheeraz-ur-Rahman S: Common presentation uncommon diagnosis primary omental torsion. J Pak Med Assoc 2013; 63(1): 117-119.

39- Chmelnik M, Lasch L, Weih S, Wink E, Romero P, Holland-Cunz S: Anastomotic sealing with a fibrin-coated collagen patch in small-diameter bowel. Langenbecks Arch Surg 2011; 396: 685-691.

40- Kolovrat M, Busic Z, Lovric Z, Amic F, Cavka V, Boras Z, S Drazen, Lemac D, Busic N: Mechanical bowel preparation in colorectal surgery. Coll Antropol 2012; 36(4): 1343-1346.

41- Cao F, Li J, Li F: Mechanical bowel preparation for elective colorectal surgery: Updated systematic review and metaanalysis. Int $J$ Colorectal Dis 2012; 27: 803-810.

42- Toneva GD, Deierhoi RJ, Morris M, Richman J, Cannon JA, Altom KL, Hawn MT: Oral antibiotic bowel preparation reduces length of stay and readmissions after colorectal surgery. J Am Coll Surg 2013; 216(4): 756-762.

43- Moloo H, Etzioni DA: Intraoperative adjuncts in colorectal surgery. Surg Clin N Am 2013; 93; 33-43.

44- Subhas G, Bhullar JS, Cook J, Shah A, Silberberg B, Andrus L, Decker M, Mittal VK: Topical gentamicin does not provide any additional anastomotic strength when combined with fibrin glue. Am J Surg 2011; 201: 339-343.

45- Vakalopoulos KA, Daams F, Wu Z, Timmermans L, Jeekel JJ, Kleinrensink GJ, van der Ham A, Lange JF: Tissue adhesives in gastrointestinal anastomosis: A systematic review. J Surg Res 2013; 180(2): 290-300.

46- Verhage RJ, Ruiz A, Verheem A, Goldschmeding R, Rinkes IHB, van Hillegersberg R: Fibrin-thrombin coated sealant increases strength of esophagogastric anastomoses in a rat model. J Surg Res 2012; 
176: 57-63.

47- Schneider A, Bennek J, Olsen KO,Weiss J, Schmidt W, Rolle U: Experimental study evaluating the effect of a barrier method on postoperative intraabdominal adhesions. Dig Dis Sci 2006; 51(3): 566-570.

48- Toro A, Mannino M, Reale G, Di Carlo
I: TachoSil ${ }^{\circledR}$ use in abdominal surgery: A review. J Blood Med 2011; 2: 31-36.

49- Anegga U, Rychlikb R, Smolle-Juattnera F: Do the benefits of shorter hospital stay associated with the use of fleece-bound sealing outweigh the cost of the materials? Int CardioVasc Thorac Surg 2008; 7: 292-296. 